\title{
Minimum inhibitory concentration (MIC) and minimum bactericidal concentration (MBC) of mangosteen (Garcinia mangostana Linn.) rind extract against Aggregatibacter actinomycetemcomitans
}

\author{
Ina Hendiani ${ }^{1}$, Agus Susanto ${ }^{1 *}$, Dyah Nindita Carolina ${ }^{1}$, Rahmat Ibrahim ${ }^{1}$, Felisha \\ Febriane Balafif ${ }^{2}$
}

${ }^{1}$ Department of Periodontics, Faculty of Dentistry Universitas Padjadjaran, Indonesia

${ }^{2}$ Department of Oral Biology, Faculty of Dentistry Universitas Padjadjaran, Indonesia

\begin{abstract}
Introduction: The main contents of mangosteen (Garcinia mangostana Linn.) is xanthone with antibacterial activity. Aggregatibacter actinomycetemcomitans (A. actinomycetemcomitans) was a gram-negative, facultative anaerobic bacillus that causes periodontal diseases such as localised aggressive periodontitis (LAP). Mangosteen rind extract could inhibit the growth of Porphyromonas gingivalis and $A$. actinomycetemcomitans. This study was aimed to determine the minimum inhibitory concentration (MIC) and minimum bactericidal concentration (MBC) of mangosteen rind extract against A. actinomycetemcomitans. Methods: This study was an experimental and in-vitro study of antimicrobial properties of mangosteen (Garcinia mangostana Linn.). The extract of mangosteen was made by the maceration method using $70 \%$ ethanol solvent. A. actinomycetemcomitans (ATCC 43718) obtained from Laboratorium of Microbiology Airlangga University Surabaya. This study used a microdilution method and analysed using the Enzyme Linked Immune Sorbent Assay (ELISA). The determination of the MIC was measured using the formula for cell inhibition percentage. Three concentrations higher than the MIC standard were cultured on the Mueller Hinton agar. The lowest concentration on agar which was not found any growth of the bacterial colonies was determined as the MBC. Results: The results of this study indicated that the MIC and MBC of mangosteen rind extract against $A$. actinomycetemcomitans were $195.3 \mathrm{ppm}$ and $1562.5 \mathrm{ppm}$, respectively. Conclusion: Mangosteen rind extract can inhibit and bactericide the growth of $A$. actinomycetemcomitans.
\end{abstract}

Keywords: Antibacterial, Aggregatibacter actinomycetemcomitans, mangosteen rind extract, xanthone.

p-ISSN: 1979-0201; e-ISSN: 2549-6212; Available from: http://jurnal.unpad.ac.id/pjd/article/view/27366

DOI: 10.24198/pjd.vol32no2.27366

Submission: May 15, 2020; Accepted: Jul 30, 2020; Published online: Jul 31, 2020

"Corresponding author: Agus Susanto, Department of Periodontics, Faculty of Dentistry Universitas Padjadjaran, Indonesia. Department of Periodontics, Faculty of Dentistry Universitas Padjadjaran, Jalan Sekeloa Selatan I, Bandung, West Java, Indonesia, 40132. Phone: +6281322416767; Email: agus.susanto@fkg.unpad.ac.id 


\section{INTRODUCTION}

Mangosteen (Garcinia mangostana Linn.) is a fruit plant that grows in tropical rainforest country such as Southeast Asia. ${ }^{1}$ Mangosteen fruit is round, dark purple or reddish, and has a juicy white pulp possessing a slightly acidic and sweet flavour that is enjoyed by many, and has resulted in it being referred to as the "queen of fruits". The pericarp of mangosteen fruit has been used in traditional medicine in Southeast Asia for centuries to treat infection, wounds, inflammation and diarrhea. ${ }^{2}$

The content of mangosteen fruit, in general, are chrysanthemin, garcinone $A, B$, and $C$, sesquiterpenoids, gartanin, fructose, sucrose, tannins, and xanthone as the main content of mangosteen rind..$^{1,3}$ Xanthone is an antioxidant, antitumor, antiallergic, anti-inflammatory, antivirus, and antibacterial. ${ }^{4}$ One of component xanthone that had antibacterial activity in the oral cavity is a-mangostin. ${ }^{5}$ Study showed that extract of mangosteen rind was effective on inhibiting the growth of gram-positive bacteria and gramnegative bacteria in vitro. ${ }^{5,6}$

Mangosteen extract has been commonly used to improve dental health by eradicating oral pathogens. ${ }^{7}$ Research by Pribadi et al. ${ }^{8}$ showed that pericarp mangosteen ethanol extract could inhibit the activity of the glucosyltransferase enzyme from Streptococcus mutans, which is essential for the development of dental caries. Furthermore, mangosteen extract including a-mangostin has been used as an anti-bacterial component in an adhesive paste to prevent dental caries. ${ }^{8,9}$

Aggregatibacter actinomycetemcomitans (A. actinomycetemcomitans) is a gram-negative, facultative anaerobic bacillus that causes periodontal diseases such as localized aggressive periodontitis (LAP) and consequently bone resorption. The potential virulence factor of this organism are factors that modulate the promotion of colonization and inflammation, factors that induce host tissue destruction, and factors that inhibit host tissue repair. ${ }^{10}$

Studies on the antibacterial ability of mangosteen have been carried out by several researchers. The pericarp gel when applied topically as an adjunct to periodontal treatment was found to enhance the clinical effects of periodontal treatment. ${ }^{11}$
Hendiani et al. ${ }^{12}$ conducted a clinical study that mangosteen rind gel as adjuntive therapy for scaling and root planing was able to reduce pockets depth, gingival index, and gingival bleeding, and improve clinical epithelial attachment. In vitro study showed that mangosteen rind extract inhibited growth $P$. gingivalis and $A$. actinomycetemcomitans with macrodilution method. ${ }^{13}$ There has been no study about antibacterial of mangosteen rind extract against $A$. actinomycetemcomitans with microdilution method. Therefore, this study was aimed to determine the minimum inhibitory concentration (MIC) and minimum bactericidal concentration $(M B C)$ of mangosteen rind extract against $A$. actinomycetemcomitans.

\section{METHODS}

This research was an experimental in-vitro study to determine the MIC and MBC extract of mangosteen rind (Garcinia mangostana L.) on the growth of $A$. actinomycetemcomitans ATCC 43718 by microdilution method. This research was conducted in February 2018 until June 2018 at the Central Laboratory of Biopharmaca Study, IPB Bogor. A. actinomycetemcomitans (ATCC 43718) bacteria were cultured from Laboratory of Microbiology Research Center UNAIR Surabaya. Mangosteen rind extract was carried out at Central Laboratory of Biopharmaca Study, IPB University Bogor. ${ }^{14}$

\section{Mangosteen rind extract}

Mangosteen rind (Garcinia mangostana L) was extracted by maceration method. It was soaked with $500 \mathrm{~mL}$ of $70 \%$ ethanol solvent for 24 hours. The immersion was filtered and immersed with ethanol again three times until a clear filtrate was obtained. Then the filtrate was concentrated using a rotary evaporator so that a thick extract without ethanol were obtained. ${ }^{12,14,15}$

\section{Preparation of test bacteria}

Gram-negative bacterial cultures of $A$. actinomycetemcomitans ATCC 43718 were inoculated into Muller Hinton Broth (MHB) media. Subsequently, it was incubated for 48 hours at $37^{\circ} \mathrm{C}$. Bacteria were inoculated into $0.9 \mathrm{ml} \mathrm{NaCl}$ solution as much as $3 \mathrm{ml}$. Then the turbidity was 
measured using a UV-Vis spectrophotometer at $\chi 600 \mathrm{~nm}$. Ten mixtures with specific ratios that produce transmittance close to $25 \%$ were used for antibacterial, MIC and MBC testing.

\section{Calculation of MIC and MBC by microdilution method}

The testing material was diluted on a microplate containing 96 microwells. To the A and C microwell columns, $100 \mu \mathrm{l}$ of Mueller Hinton broth (MHB) and $100 \mu \mathrm{l}$ of solvent (dimethyl sulfoxide) were added to a concentration of 100,000 ppm. Microwell columns $B$ and $D$ were added $100 \mu \mathrm{l}$ of Mueller Hinton broth (MHB) media and 100 $\mu \mathrm{l}$ of mangosteen rind extract which had been dissolved to obtain a concentration of 100,000 ppm. After that, a serial dilution of row 1 to 12 microwell was carried out. Then the suspension of A. actinomycetemcomitans ATCC 43718 (5 $\mu \mathrm{l})$ was put into all microwells in columns $C$ and $D$. The microplate was then incubated at $37^{\circ} \mathrm{C}$ for 24 hours and measured turbidity level by using ELISA
Reader (Epoch ${ }^{T M}$ Microplate Spectrophotometer, United States). The determination of the MIC was measured using the formula for cell inhibition percentage ${ }^{15}$, with: Optical Density (OD) control obtained from $\mathrm{OD}$ (media, solvent, bacteria) reduced by $\mathrm{OD}$ (media, solvent); $\mathrm{OD}$ sample obtained from $\mathrm{OD}$ (media, testing material, bacteria) reduced by $\mathrm{OD}$ (media, testing material). $M B C$ was determined by testing three concentrations higher than MIC carried out subculture on Mueller Hinton agar medium and incubated at $37{ }^{\circ} \mathrm{C}$ for 48 hours. Media without bacterial colonies was determined as MBC.

\section{RESULTS}

Three concentrations above the minimum inhibitory concentration were regenerated on the Mueller Hinton agar medium at 195.3 ppm. The minimum bactericidal concentration showed agar plates showed no bacterial growth at a concentration 1562.5 ppm (Figure 1).

Table 1. The measurements of optical density using ELISA reader after incubation

\begin{tabular}{|c|c|c|c|c|c|c|c|c|c|c|c|c|}
\hline \multirow{2}{*}{ Well } & \multicolumn{12}{|c|}{ Concentration (ppm) } \\
\hline & 100000 & 50000 & 25000 & 12500 & 6250 & 3125 & 1562.5 & 781.25 & 390.6 & 195.3 & 97.6 & 48.5 \\
\hline MS & 0.096 & 0.098 & 0.097 & 0.168 & 0.330 & 0.097 & 0.097 & 0.096 & 0.185 & 0.927 & 0.111 & 0.247 \\
\hline MT & 2.122 & 1.065 & 0.616 & 0.431 & 0.300 & 0.136 & 0.134 & 0.117 & 0.178 & 0.337 & 0.303 & 0.352 \\
\hline MSB & 0.611 & 0.469 & 0.480 & 0.586 & 0.374 & 0.566 & 0.608 & 0.282 & 0.071 & 0.369 & 0.406 & 0.355 \\
\hline MTB & 2.221 & 1.371 & 0.843 & 0.371 & 0.680 & 0.429 & 0.421 & 0.133 & 0.285 & 0.305 & 0.614 & 0.703 \\
\hline
\end{tabular}

ppm (part per million); MS (Media + Solvent); MT (Media + Testing Material); MSB (Media + Solvent + Bacteria); MTB (Media + Testing Material + Bacteria)

Table 2. Percentage of inhibition of bacterial cells of $A$. actinomycetemcomitans in mangosteen rind extract

\begin{tabular}{cc}
\hline $\begin{array}{c}\text { Concentration } \\
(\mathrm{ppm})\end{array}$ & \% Inhibition A. actinomycetemcomitans \\
\hline 100000 & 80.78 \\
50000 & 17.52 \\
25000 & 40.73 \\
12500 & 114.35 \\
6250 & -763.64 \\
3125 & 37.53 \\
1562.5 & 43.84 \\
781.25 & 91.39 \\
390,6 & 193.86 \\
195.3 & 94.26 \\
97.6 & -5.42 \\
48.5 & -225 \\
\hline
\end{tabular}

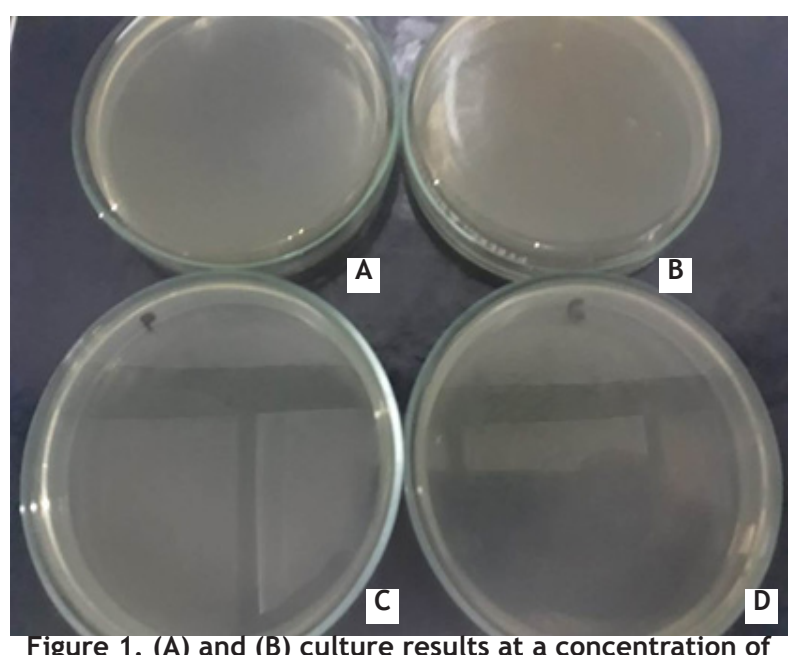

Figure 1. (A) and (B) culture results at a concentration of 781.25 ppm; (C) and (D) culture results at a concentration of $1562.5 \mathrm{ppm}$ 


\section{DISCUSSION}

This study showed that mangosteen extract could inhibit and kill $A$. actinomycetemcomitans with MIC value of $195.3 \mathrm{ppm}$ and MBC value of 1562.5 ppm. Although with different concentrations, these findings were following the previous study by Hendiani et al. that showed inhibitory and bactericidal power of mangosteen rind extract against $A$. actinomycetemcomitans. ${ }^{13}$ This study uses the microdilution method that is more sensitive than macrodilution in the previous study. Mangosteen rind extract has an antibacterial activity which is similar to the research conducted by Suhartati et al. ${ }^{16}$, which is suggested that the antibacterial effect of mangosteen rind extract is having a difference on the gram-negative and anaerobic bacteria. Phytochemical screening test of mangosteen rind showed that the ethanol extract of mangosteen rind contained active compounds, such as chrysanthemin, garcinone A, $B$, and $C$, sesquiterpenoids, gartanin, fructose, sucrose, tannins, and xanthone as the main content of mangosteen rind. Xanthone compounds can inhibit growth bacterial ${ }^{3,5}$, as also found in the study conducted by Dharmaratne ${ }^{17}$ on xanthone from mangosteen rind extract against S.aureus and Enterococcus bacteria. ${ }^{3}$

Xanthones are the most important chemical content in mangosteen rind. The main compounds of xanthones include a-mangostin, B-mangostin, $\gamma$-mangostin, and methoxy- $B$-mangostin. One of component xanthone that has antibacterial activity in the oral cavity is a-mangostin. The antibacterial activity of xanthone has complex compounds against extracellular proteins that interfere the integrity of the bacterial cell membrane. Also, xanthones are capable of coagulating proteins that cause the bacterial cell membrane to become lysis. $5,16,18$

Tannins will coagulate bacterial cells and eliminate toxins. Tannins can shrink and interfere with the permeability of bacterial cell membrane. Permeability disruption of bacterial cells causes their growth is stunted or dead. ${ }^{5,16}$

This study was still in vitro tests; therefore, it did not reflect the real condition found in periodontal pockets. It did not consider the factors such as the interaction of host, agent, and environment. The crude form of mangosteen was used in our study, and the primary active compound in mangosteen was not isolated and identified. Further studies shall be done to determine active antibacterial compounds against periodontal disease bacteria. In vivo studies should be conducted to prove its antibacterial activity against periodontal microorganisms without causing significant local or systemic adverse effects.

\section{CONCLUSION}

Mangosteen rind extract can inhibit and bactericide the growth of $A$. actinomycetemcomitans.

\section{REFERENCES}

1. Yang R, Li P, Li N, Zhang Q, Bai X, Wang L, et al. Xanthones from the pericarp of Garcinia mangostana. Molecules. 2017; 22(5): 683-93. DOI: $10.3390 /$ molecules 22050683

2. Gutierrez-Orozco F, Failla ML. Biological activities and bioavailability of mangosteen xanthones: A critical review of the current evidence. Nutrients. 2013; 5(8): 3163-83. DOI: 10.3390/nu5083163

3. Lim TK. Edible Medicinal and Non-Medicinal Plants: Volume 11 Modified Stems, Roots, Bulbs. New York: Springer; 2012. pp. 83-100.

4. Shan T, Ma Q, Guo K, Liu J, Li W, Wang F, et al. Xanthones from mangosteen extracts as natural chemopreventive agents: Potential anticancer drugs. Curr Mol Med. 2011; 11(8): 666-77. DOI: $10.2174 / 156652411797536679$

5. Torrungruang K, Vichienroj P, Chutimaworapan S. Antibacterial activity of mangosteen pericarp extract against cariogenic Streptococcus mutans. CU Dent J. 2007; 30: 1-10.

6. Nguyen PTM, Marquis RE. Antimicrobial actions of a-mangostin against oral Streptococci. Can J Microbiol. 2011; 57(3): 217-25. DOI: 10.1139/W10-122

7. Aizat WM, Jamil IN, Ahmad-Hashim FH, Noor NM. Recent updates on metabolite composition and medicinal benefits of mangosteen plant. PeerJ. 2019; 7: e6324. DOI: $10.7717 /$ peerj.6324

8. Pribadi N, Yonas $\mathrm{Y}$, Saraswati W. The inhibition of Streptococcus mutans glucosyltransferase 
enzyme activity by mangosteen pericarp extract. Dent J (Maj Ked Gi). 2017; 50(2): 97 101. DOI: 10.20473/j.djmkg.v50.i2.p97-101

9. Sodata P, Juntavee A, Juntavee N, Peerapattana J. Optimization of AdhesivePastes for dental caries prevention. AAPS PharmSciTech. 2017; 18(8): 3087-96. DOI: 10.1208/s12249-0170750-0

10. Gholizadeh P, Pormohammad A, Eslami $H$, Shokouhi B, Fakhrzadeh V, Kafil HS. Oral pathogenesis of Aggregatibacter actinomycetemcomitans. Microb Pathog. 2017; 113: 303-11. DOI: 10.1016/j. micpath.2017.11.001

11. Shah R, Gayathri GV, Mehta DS. Application of herbal products in management of periodontal diseases: A mini review. Int J Oral Health Sci. 2015; 5(1): 38-44. DOI: 10.4103/2231$\underline{6027.171166}$

12. Hendiani I, Hadidjah D, Susanto A, Pribadi IMS. The effectiveness of mangosteen rind extract as additional therapy on chronic periodontitis (Clinical trials). Padjadjaran J Dent. 2017; 29(1): 64-70. DOI: 10.24198/pjd. vol29no1.12986

13. Hendiani I, Hadidjah D, Susanto A, Pribadi IMS. Inhibitor and bactericidal power of mangosteen rind extract towards Porphyromonas gingivalis and Actinobaccillus actinomycetemcomitans (Laboratory test). Padjadjaran J Dent. 2016; 28(2): 75-80. DOI:

\subsection{8/pjd.vol28no2.13605}

14. Poeloengan M, Praptiwi P. Uji aktivitas antibakteri kulit buah manggis (Garcinia mangostana Linn). Media Health Res Dev. 2010; 20(2): 65-9.

15. Azhar IS, Kresnoadi U, Rahayu RP. Potency of Garcinia mangostana $L$ rind extract combined with demineralized freeze-dried bovine bone xenograft on IL-1B expression, osteoblast, and osteoclasts in alveolar bone. Dent J (Maj Ked Gi). 2017; 50(3): 166-170. DOI: 10.20473/j. djmkg.v50.i3.p166-170

16. Suhartati R, Apriyani F, Khusnul, Virgianti DP, Fathurohman M. Antimicrobial activity test of Mangosteen leaves ethanol extract (Garcinia mangostana Linn) against Pseudomonas aeruginosa bacteria. J Phys. 2019; 1179: 012167. DOI: 10.1088/17426596/1179/1/012167

17. Dharmaratne HR, Sakagami Y, Piyasena KGP, Thevanesam V. Antibacterial activity of xanthones from Garcinia mangostana (l.) and their structure-activity relationship studies. Nat Prod Res. 2013; 27(10): 938-41. DOI: 10.1080/14786419.2012.678348

18. Geetha R, Roy A, Lakshmi T. Evaluation of antibacterial activity of fruit rind extract of Garcinia mangostana Linn on enteric phatogens-an in vitro study. Asian J Pharm Clin Res. 2011; 4(2): 115-8. 